\title{
Bringing together social-ecological system and territoire concepts to explore nature-society dynamics
}

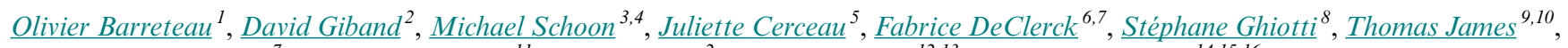 \\ Vanessa A. Masterson $^{7}$, Raphael Mathevet $^{11}, \underline{\text { Sylvain Rode }}^{2}$, Francesco Ricci $^{12,13}$ and Clara Therville $^{14,15,16}$
}

\begin{abstract}
We examine two academic traditions that address the nature-society interface. These traditions are organized around two main concepts: social-ecological system and territoire. These traditions have grown independently and are rooted respectively in ecology and social geography. We show that they have much in common: Both come with a systemic view of the nature-society interface and have the intention of understanding better the relations between nature and society and improving their sustainability. However, they differ in how they deal with space and society. We foresee that the combination of both traditions could improve the understanding of these systems, their definition, and their evolution, and hence, the capacity to assess and manage their resilience.
\end{abstract}

Key Words: flows; power; sense of place; social-ecological system; territoire

\section{INTRODUCTION}

In their activities, people continuously adapt to their situation, with goals that shift in response to changes in their environment. When interviewed about climate change, farmers in southern France suggest that adaptation is intrinsic to their activities (Faysse et al. 2014). Through constant interaction with their environment, they adjust their techniques and practices to moderate the consequences of environmental change on their livelihood. In doing so, they shape the configuration and trajectory of southern France's landscape, for example, through investments in new irrigation devices or changes in cropping patterns to cope with the occurrence of droughts. However, suitable adaptation actions at one's own scale of reference are not always reachable. In these cases, people have to change more radically, with actions, either intentional or unintentional, that push toward a regime shift or a change in the social-ecological system (SES) within which they are embedded.

In the analysis of relations between people and their environment, we assume that people assess the status and state of their environment primarily through self-reflection on their own life condition. People feel they have the capacity to maintain or improve their condition through their relations to others and their physical environment. Our second assumption is that the core variables of life condition are relative to each person, but some are shared and many interact. As a consequence, the coordination of adaptation patterns for society is required. A key issue is then to identify meaningful "systems" where such coordination is expected, either through the density of interactions or as social intent. Defining and naming these emerging systems by building on existing conceptual frameworks are the key issues we address here. We consider resilience, i.e., the "capacity of a system to absorb disturbance and reorganize while undergoing change so as to still retain essentially the same function, structure, identity, and feedbacks" (Walker et al. 2004), as a property of these systems. This property integrates the components' capacities to maintain collectively individual livelihoods and a shared core identity. Permanence of the major interactions embedded in local society and local natural environment is a central indicator of this resilience because network characteristics are among the determinants of its strength (Janssen et al. 2006). The way we define these emerging integrated systems is then crucial to assess collective resilience.

The issue is to delineate clearly the system components involved in these core interactions. There is a fundamental need for concepts and words to characterize what is formed by this set of interactions so that we might understand their dynamics and sources of change and assess the system's resilience. Two parallel academic traditions provide useful interdisciplinary conceptual frameworks to understand and explore nature-society systems: ecological and institutional analysis building on the concept of social-ecological systems (SESs; Berkes and Folke 1998, Gallopín 2006), and social geography using the francophone originated concept of territoire (Le Berre 1995, Debarbieux 2004). To our knowledge, these two traditions have not yet been compared. We argue here that they have much in common, and we try to demonstrate their potential for mutual benefit. By considering them in parallel, we enhance the understanding of the contributions of these traditions to resilience assessment, mainly in answering the question "Resilience of what?" (Carpenter et al. 2001). For scholars involved in analysis or action research related to nature-society relations, we aim to provide an enhanced conceptual toolbox to identify the systems at stake while limiting omissions of key interactions that could have a cascading influence on system dynamics. We aim to answer whether the

${ }^{1}$ IRSTEA, UMR G-EAU, ${ }^{2}$ Université de Perpignan, Via Domitia, UMR 5281 ART-Dev, ${ }^{3}$ Center for Behavior, Institutions, and the Environment, ${ }^{4}$ School of Sustainability, Arizona State University, ${ }^{5}$ UMR PACTE, ${ }^{6}$ Bioversity International, ${ }^{7}$ Stockholm Resilience Centre, Stockholm University, ${ }^{8} \mathrm{CNRS}$, UMR 5281 ART-Dev, ${ }^{9}$ Environment and Sustainability Institute, University of Exeter, ${ }^{10}$ Centre for Science and Technology Policy Research, University of Colorado Boulder, ${ }^{11}$ CNRS, UMR 5175 CEFE, Montpellier, France, ${ }^{12}$ Université de Montpellier, ${ }^{13}$ UMR 5281 ART-Dev, ${ }^{14}$ CNRS, UMR 5175 CEFE, ${ }^{15}$ EA 2119 Géoarchitecture, Université de Bretagne Occidentale, ${ }^{16}$ Réserves Naturelles de France 
understanding of territoire (a real-life and symbolic or landowned space), as a complex system whose characteristics and dynamics are based on the interactions between actors and their spatially explicit ecological context, provides an operational approach for understanding social-ecological interactions.

We first present definitions of both of the concepts and specific academic traditions in which our arguments are embedded. We then focus on common roots identified with systems, space, and society, and their various interpretations. We suggest several ways to build bridges between both concepts. Finally, we discuss the potential for enhanced understanding of the nature-society relation with the articulation of both concepts. In sum, this work is the result of reflection and discussion that occurred during and after a workshop in November 2013 that brought together scholars of the SES approach and social geographers working on territoire to compare and discuss the concepts while preparing for the Resilience 2014 conference (http://www.resilience2014.org/).

\section{DEFINITIONS AND GENEALOGY OF THE TRADITIONS AND CONCEPTS}

\section{What is a territoire?}

The notion of territoire gained popularity among Frenchspeaking social scientists over the last three decades. It is mostly used by French-speaking social geographers, but has received some use beyond the francophone community. We have not translated the term to "territory" because that word is commonly used in relation to administrative boundaries. Here, we focus on the use of territoire within a social geography perspective. Originally developed from spatial appropriation and political control rooted in the making of the nation-state (Weber 1978, Sassen 2008), the concept was mainly used in ethology from the 1920 s to the 1960 s, after which it was brought back into the humanities by anthropologists, sociologists, and geographers, who suggested that one can better understand human behavior by studying how a group takes ownership of a territoire through processes of identity and belonging. Defined in social geography as a spatial mediator of all social life (Di Méo 1999), territoire is both a social and a lived space, including political and ideological dimensions of space. Raffestin (1986:177) stated, "Territoire is a reordering of space (...) it can be considered as the informed space of the biosphere."

In the 1980s, francophone academics in human geography constructed and used territoire as an operative concept to understand relationships between societies and their environment (Di Meo 1998). The term gained popularity in reaction to quantitative and spatial approaches dealing with the notion of space in "the absolute mode" (Agnew 2011:322). Disputes among geographers deal with the nature of space. Referring to Lefebvre (1974), social geographers understand territoire following the dialectics of space. Territoire is socially produced, conflictual, and a medium for social representations (Séchet and Veschambre 2006). This focus takes a holistic approach to account for the complexity of social phenomena in their spatial dimensions (Rougerie and Beroutchavili 1991). Social geography (i.e., the branch of human geography that focuses on social theories and their spatial components) considers territoire in its economic, ecological, ideological, and political dimensions (Di Méo and Buléon 2005). Complexity hinges on the importance that individuals and groups place on their connections and relationships with a physical space (Raffestin 1986).

Evolving from its ethological sense, territoire describes how individuals and groups act, think, behave, and deploy and implement strategies inside a given controlled space. In other terms, territoire emerges through the interactions that individuals and groups have with their environment within a specific geographical area (Debarbieux 2007). Thus, it can be seen as a socio-spatial system at different spatial scales (local, regional, national, global), which is embedded in a physical space and socially produced, including both material and immaterial dimensions (Berque 2000). The material dimension refers to both the physical and ecological nature of space. The immaterial dimension refers to social representations, ideas, images, and imageries produced within a specific space, which transform space into territoire, making it socially and culturally invested (Debarbieux 2003, Ferrier 2003).

In this complex socio-spatial system, society and actors act in a given space while space and its biophysical components act on societies and actors with their social and cultural representations, heritage, and other factors (Vant 1986). Di Méo (1987:561) suggests introducing "the spatial dimension, proposed as an additional criteria in social distinction and classification." As such, there is a bidirectional feedback loop between the social systems and the biophysical system. These complex systems are theorized as socio-spatial combinations (Di Méo and Buléon 2005) composed of infrastructures (landscapes, communication networks, geology) and a superstructure (cultural and social schemes, policy, power). Increasingly, environmental issues have come to the center stage of this body of research while recognizing society's dependence on environmental components of the system: the experience and management of environmental risks (Duchêne et al. 2004), the development of biodiversity conservation policies, and the use of environmental symbols in cultures and strategies (Lepart and Marty 2006, Mathevet and Godet 2015). Many social scientists investigate the territorial construction of environmental resources (Bonnefoy et al. 2000, Gumuchian and Pecqueur 2007), whereas other research focuses on environmental risks and their consequences on territoire with a focus on its resilience (Coanus et al. 2010). This conception of territoire leads to environmental planning approaches that put emphasis on natural environmental systems (Selman 2000) and feed discussion on the management of landscape dynamics inherited from both cultural and natural processes.

With territoire growing ever more popular in the 1980s and 1990s, the word has become increasingly polysemous. Criticisms emerged on the imprecise use and inadequacy of the notion of territoire in a globalized context (Badie 1995). Agnew (1994:57) coined the term "territorial trap," referring to the nonsense of an idealized notion of territoire contained within well-defined boundaries. Anglo-Saxon geography has long constrained territoire (i.e., territory) to political geography, regarding it as the spatial basis of power, inspired by Foucault and Lefebvre (Fall 2007), and paying attention to borders, controls, and state regulation (Sack 1986). The meaning reserved for the notion of place is close to territoire. Place is understood as a term mixing location on the Earth's surface, a locus of individual and group identity, and the scale of everyday life (Castree 2014). Places are 
seen as "glocal": local actions responding to but also influencing wider sets of rules and relationships at different scales (Cresswell 1996). There is a conceptual proximity between place and territoire because both terms carry not only spatial reference but also social and moral references (Tuan 1979). Since the 2000s, territoire has been assessed for its own specificity by Anglo-Saxon geographers. In this trend, Elden (2010) points out that one should consider a territoire in its historical perspective, building on the Foucauldian root of the concept. A number of techniques and laws contribute to drawing the picture of territoire as a politicaltechnological-social construct. Today, the concept continues to evolve. For instance, following Vanier (2008), many social scientists associate networking and mobility analysis with territoire and introduce new concepts such as multiterritorialities, establishing connections between socio-spatial dynamics of territoire (as a local and contiguous geographical area) and reticular logics of networks (Cortes and Pesche 2013).

\section{What is a social-ecological system?}

To provide the context for our comparison between territoire and SESs, we first provide an overview of SESs. Similar to the previous section on territoire, SESs constitute another tradition tackling the relationship between a society and its environment. SESs are linked or coupled human-environmental systems and represent a movement of two mirror images coming together. The first image is that of ecologists and other natural scientists increasingly focusing on the social dimensions of environment and ramifications of the human world as integrated in and a part of the natural world, rather than an external source of disturbances on ecosystems (Berkes and Folke 1998, Folke 2006). The second image is of social scientists noting how the biogeophysical context directly affects people, their institutional arrangements and culture, and society as a whole. Again, the movement is toward a holistic view of the social and ecological as a single system with effects and feedbacks from one subsystem to the other or as a single complex system (Gallopín et al. 1989, Folke 2006).

In SESs, the system is an integrated whole comprising multiple social agents and biophysical elements that have some level of connectivity and interaction (Meadows 2008). Ostrom (2007) and colleagues have proposed a characterization of SESs that includes four important subcomponents: (1) users, (2) governance systems, (3) resource units, and (4) resource settings. This organization recognizes that these subunits interact to produce outcomes and are embedded in social, economic, and political settings as well as biophysical ones. SESs are often referred to as complex adaptive systems with dynamic interactions at multiple scales (Folke 2006), leading to the generation of outputs in which the aggregate behavior emerges from the interactions of multiple individual agents and is qualitatively different than the sum of the individual behaviors in that it cannot be inferred from the behavior of any single individual entity (Miller and Page 2009). Often SESs are considered as exhibiting a degree of self-organization in which the system organizes without any central control (Mitchell 2009).

Much of the ecological foundational work on SESs draws on the work of C. S. Holling. Holling's (1973) work on cybernetics and systems dynamics coincided with the understanding of complex adaptive systems. This research fomented much early work on the resilience of ecosystems, highlighting the importance of nonlinearities, thresholds, and multiple equilibria in systems. The uncertainties inherent in these system characteristics contrasted with much of ecological understanding at the time, which took an unrealistic, but mathematically tractable, equilibrium approach to the field. The high levels of uncertainty inherent in studying ecosystems led Holling to expand his research into adaptive management and understanding a system out of necessity (Holling 1978). This foray into management, and later work that looked at command and control approaches to natural resource management (Holling and Meffe 1996), increasingly involved social elements as integral parts of the system at stake. This trend led to the study of SESs to understand complex coupled human-environment interactions.

Natural scientists were moving toward these coupled complex systems approaches (e.g., Levin 1999) and reaching out to social scientists (Gunderson et al. 1995). Simultaneously, social scientists were also drawing on complexity and systems perspectives such as the work of Axelrod and Hamilton (1981) to explain the emergence of cooperation. Throughout the 1990s, Ostrom and colleagues used their Institutional Analysis and Development framework to begin to combine the biophysical context and societal variables to understand institutional arrangements as they are affected by changes in the system (Ostrom et al. 1994). Berkes and Folke (1998) took the next step and brought social and natural scientists together in the analysis of coupled SESs.

The concept of the SES continues to gain popularity, requiring interdisciplinary teams, approaches, and methods. More recent efforts to integrate this field of study and deepen our understanding include applied robustness frameworks (Anderies et al. 2004) and the continuing development of Ostrom's SES framework (Ostrom 2009, McGinnis and Ostrom 2014). As a consequence, the conceptual apparatus of the SES is expanding, including mental models of agents to incorporate knowledge dynamics (Gray et al. 2012), or infrastructures as mediators and affordances in system dynamics (Anderies 2015).

More recently, SESs have garnered additional attention and use, specifically with the aim of reconciling "wicked" problems of natural resource management and its effects on humanity. For example, Mace (2014) makes the point in her recent work on "whose conservation" by arguing that the domain of conservation biology has evolved from largely nature based to its current paradigm of considering both nature and people, building key ideas embedded in environmental change, resilience, adaptability, and SESs. The SES tradition leads its practitioners to investigate issues such as the consequences of gradual environmental change and the capacity for society to cope with change. For example, how do gradual changes such as accumulation of pollutants, habitat loss, or changes in societal values slowly erode the strength of the dominant feedbacks in a system until a threshold is reached and a different set of feedbacks suddenly becomes dominant, leading the system to reorganize rapidly into a new regime? What knowledge systems and social learning systems are required to navigate these regime shifts? From a practical point of view, SES studies attempt to resolve questions of human and environmental conflict, frequently addressing how groups organize, formally or informally, to manage common-pool resources, paying attention to the contingency of specific landscapes (Walker et al. 2004, Kinzig et al. 2006). The notion of SESs is also largely embedded 
in development paradigms and, as such, is outcome driven with specific aims or goals around sustainability from either the human or environmental dimensions (Adger 2000).

\section{SYSTEM, SPACE, AND SOCIETY: COMMON ROOTS, WITH DIVERGENCES}

Both SES and territoire share interdisciplinary concepts to explore nature-society dynamics. Both concepts identify sets of interactions with components of different natures, including social and ecological ones. Both traditions converge toward analyzing the coevolution of these components as they are framed by this network of interactions. Hence, both accept the notion of either SES or territoire as complex adaptive systems (Moine 2006), with social components pushing the interactions and physical space orienting them as their privileged medium. To understand the possible evolution of these complex systems, we need to be able to examine key components and interactions. Our purpose in pushing the comparison of both traditions is to enable a more thorough analysis of these nature-society systems and to establish the suitability of mixing elements of both, as well as identifying the potential benefits of such mixing. We first compare both traditions and their handling of interactions between nature and society. Second, we review the means by which each tradition engages in system thinking, how they use the notion of space, and their approach in addressing societal change and decisionmaking.

\section{Nature-society interactions}

Both SES and territoire are used to represent the interactions between ecological and social spheres as a knowable unit of study for the evolution of land and resource planning and management. They build on various trends dealing with this intersection for the sake of natural resources management, including sustainable development (WCED 1987), with acknowledgement of social, ecological, and economic components as joint drivers of development. SES features categories of users or systems of resources that enable accounting for these strong interactions. In contrast, territoire builds on representations based on landscapes, including the articulation of resources, and social and political schemes as SES components.

SES and territoire differ in their way of understanding humans and the relative weight given to nature and society in these interactions. Where territoire tradition considers actors as individuals that act on their environment (Di Méo and Buléon 2005) or inhabitants as individuals that think and build spaces (Hoyaux 2002), SES tradition often considers users and stakeholders (Ostrom 2007) with a strategic relation to their environment. Although both epistemologies handle relationships between nature and society, SES tradition starts with ecology or a scoping of the natural resource base, considered as an operating space for society, and brings in a continuous extension toward institutional analysis (Cote and Nightingale 2012). In contrast, territoire tradition starts with social perspectives and, taking a nondeterministic approach to geography, considers that humans can modify nature and move away from its constraints (Ferrier 1984). These nature-society interactions, understood as territoire, could only be defined through the relationship humans develop with space and time (Di Méo and Buléon 2005). Hence territoire tradition uses a constructivist approach, with nature emerging through perceptions and interactions with society, whereas nature has its own existence in SES tradition. As a consequence, SES tradition can more easily incorporate knowledge coming from physical and biological sciences.

\section{System approach}

Both traditions build on the concept of system, as introduced by von Bertalanffy (1968). They adopt the same three-dimensional description and analysis of a system: functional, structural, and dynamic (Checkland 1981). They also share the view that a system, particularly its structure, should be studied through three lenses: physical, including components, phenomena, facts, and elements; logical, looking at the relationships between components that determine the functioning and evolution of the system; and holistic, defining the identity of the system. Both traditions consider that system identity emerges from the interactions between the components and gives meaning to these interactions (Wilson 1990, Deffontaines et al. 2000, Holling 2001).

Analyses of SES and territoire adopt a similar stance concerning scales and levels of organization: time, space, and social groups (Mathevet et al. 2003, Cote and Nightingale 2012). The evolution of the system depends not only on present conditions but also on past disturbances. Long-term social-ecological research highlights the pathways, regimes, and transitions of both SES and territoire. For instance, Singh et al. (2013) provide understandings of the SES characteristics that frame the management of resources and its evolution in time. Barles (2009) proposes an adaptation of long-term social-ecological methods to the localized scale of territoire. The time dynamic is examined in territoire tradition through the production of the narratives that explain the sequence of nature-society relations producing the territoire. In SES tradition, the temporal dynamics are acknowledged through studying interactions between slow and fast variables, understanding path dependencies and dynamic models of the system. Cross-scale interdependences from determinants set by large spatial entities or social groups and organizations are also demonstrated through both traditions (Gunderson and Holling 2002, Lévy 2003).

While sharing a number of points of view on system analysis, SES and territoire traditions diverge in their view of systems in the relative weights given to various dimensions of system descriptions. SES focuses more on functions, whereas territoire focuses more on structure. As a consequence, analyses of these systems originally involve flows and feedbacks related to functions for SES, whereas connections of layers make up the whole for territoire. Whereas the territoire tradition defines interactions, relationships, and representations between humans and their environment, the SES tradition conceptualizes the origin and regulation of flows and feedbacks (Walker et al. 2006) with an increasing focus on the agency behind these (Ostrom et al. 1994). Lastly, SES tradition describes a hierarchy of systems and system components within a nested system (Gunderson and Holling 2002, Ostrom 2007). In contrast, territoire tradition explains the representations and uses actors have of a biophysical and spatial organization of a specific area, and the contribution of these multiple representations to social phenomena such as sense of place (Clark and Stein 2003). As a consequence, dynamics in a territoire-based analysis come from individual and political choices, whereas an ecosystem perspective frames matters more in SES tradition. 


\section{Space}

Territoire is naturally embedded in space, which provides the objective biogeochemical substrate within which human actors interact to represent and construct a territoire. Functions of SES depend on the location of natural biophysical elements and their stocks and flows in the function of human activities and interventions.

Defining space, however, highlights the challenges of boundaries, i.e., the spatial limits of the system. In both epistemologies, the clarity of boundaries has faded because of the relativism of definitions, being in both cases acknowledged as depending on analyst and stakeholder viewpoints. Integration of individual viewpoints makes it difficult to delineate boundaries that make sense for all components of the system.

The importance given to space differs between the traditions. Territoire tradition aims at building representations of spatial realities via discourses, photography, and cartography (Di Méo and Buléon 2005) working as stories of space (de Certeau 1990). The enhancement of geographical knowledge proceeds by adoption and transformation of these representations of space (Debarbieux 2004). In SES, results are not necessarily spatially projected (Cumming et al. 2006), and system components can be determined or described without specified geographic boundaries or spatial references. However, spatial mismatches between social and ecological systems are a matter of concern for SES scientists (Carpenter et al. 2001, Walker et al. 2004). Space is but one possible dimension of interactions between nature and society.

\section{Relation to society}

Both SES and territoire consider society as essential to their existence and to the dynamics of change. They integrate an analysis of agency triggering changes or sequences of decision and negotiation producing narratives of evolution. They also aim to bring into policy arenas the knowledge produced by research to generate science-policy interactions. This relation to society is ambiguous in many cases because several practitioners of both traditions have the simultaneous goal of describing society as a part of the system and its dynamics, but also being part of the change itself, guiding collective action, be it for more sustainability, economic efficiency, or social justice.

SES and territoire face this tension around decision-making, issues of power, and consideration of humans in diverging ways. SES analysis primarily focuses on understanding system functions. When decision-making is considered, including feedbacks toward system governance, SES tradition appears to be more subject to an action research stance, with a focus on learning and adaptive capacity (Fazey et al. 2007, Fabricius and Cundill 2010, Béné et al. 2011). In contrast, social geographers take a more critical stance, including stepping back and engaging in raising potential issues of inequities held by conceptual choices (Foster and Clark 2008, Hornborg 2009, Cote and Nightingale 2012). Although this reflexivity is not specific to any of these traditions, we observe a difference in its practice. This affects how power issues are considered: social geographers are more concerned about the consequences of their work on power balance and social justice, whereas SES analysts focus more on power relations as controls on flows or feedbacks among components. This divergence in dealing with this tension regarding intervention is the root of one of the main dimensions of debate among both traditions (see Debates: Potential for Enhanced Understanding of the Nature-society Relation?).

\section{Synthesis of comparison}

Territoire and SES traditions share several conceptual, methodological, and operational features. This paves the way for more cross-fertilization between the two traditions. However, they are still based on two different epistemological frameworks with different underlying postulates and objectives. These differences can lead to biases in their analysis (Table 1). We assume that most of these discrepancies do not come from irreducible stances, but that they might complement one another to strengthen the analysis of nature-society interactions that can be produced and used. We next suggest pathways to, and benefits of, bridging the traditions.

\section{POTENTIAL AND EXISTING BRIDGES BETWEEN THE TWO TRADITIONS}

Beyond similarities and differences, bridging requires a thorough verification of the consistency of one concept against the conceptual framework with which we try to incorporate it. We first consider some of the concepts originating from SES followed by those from territoire.

\section{Flows, feedback, and evolution}

Several analyses of SESs describe and measure flows of materials and energy occurring within a given space (Chertow et al. 2013). These flows are analyzed as a result of interactions within the SES. SES approaches to studying flows can enhance territorial knowledge. For example, Barles (2009) computes the material balance for Paris, France, pointing at the link between urban metabolism and density of activities, which highlights interactions between territorial planning and economic development, an analysis that complements those based on territoire. This addition of flows within territoire analysis entails completing the portfolio of interactions that are considered in trade-offs and negotiations. Economics has pointed out the existence of externalities due to material flows that are not managed (e.g., nonpoint source pollution due to heavy use of pesticides and fertilizers in agriculture). Current governance systems are challenged in accounting for these externalities because of a lack of valuation systems and institutions to handle them (Sarker et al. 2008, Martin and Stahn 2013). Adding an extensive flow analysis, including the agency involved in these flows, should better inform these governance processes.

Beyond material and energy flows, SES analyses study dynamic interactions through feedback loops acting directly or indirectly across the SES and involving changes in behavior, decision, and adaptation (Cumming et al. 2006, Folke 2006). Interacting agents use perceived feedbacks in their decision processes. Feedback loops manifest within and across multiple temporal and spatial scales in nested SESs and act as helpful lenses for understanding change in complex human-nature systems (Liu et al. 2007). SES experience in considering various temporal and spatial scales within a unified but modular framework is potentially useful for territorial analysis. Feedback loops are essential to understand the complexity of territoires and to avoid the territorial trap raised by Agnew (1994): reciprocal feedbacks at a larger spatial scale interact with the local spatial scale in the long term. For example, the production of nutrients in agriculture may improve farmer 
Table 1. Main differences between the two traditions for studying nature-society dynamics: territoire and social-ecological system (SES).

\begin{tabular}{|c|c|c|}
\hline Characteristic & Territoire & SES \\
\hline Priorities & Understand humans in their environment & $\begin{array}{l}\text { Understand nature and society as a complex } \\
\text { adaptive system; } \\
\text { Guide management for environmental } \\
\text { sustainability and human well-being; } \\
\text { Identify actors, processes, and beneficiaries of } \\
\text { social institutions and arrangements }\end{array}$ \\
\hline \multirow{6}{*}{$\begin{array}{l}\text { Relation to system } \\
\text { thinking }\end{array}$} & Structure & Functions and relationships \\
\hline & Interactions & Flows and feedbacks \\
\hline & Different layers & Hierarchy of systems \\
\hline & Holistic level: identity, sense of place & Nested system \\
\hline & $\begin{array}{l}\text { Interactions between actors and their } \\
\text { representations }\end{array}$ & Subsystems \\
\hline & Biophysical and spatial dimensions & Components \\
\hline Consideration of people & Inhabitants, actors & Users, stakeholders \\
\hline $\begin{array}{l}\text { Temporal issues } \\
\text { (historical and } \\
\text { prospective approaches) }\end{array}$ & $\begin{array}{l}\text { Historical approach: embodies history (the } \\
\text { territoire is the result of past actions, uses, and } \\
\text { representations) }\end{array}$ & $\begin{array}{l}\text { Dynamic/evolution approach: mechanisms and } \\
\text { transformation }\end{array}$ \\
\hline Spatial issues & More explicit reference to space & Often, but not necessarily, spatially explicit \\
\hline $\begin{array}{l}\text { Link with decision- } \\
\text { making }\end{array}$ & $\begin{array}{l}\text { A critical approach coexists with decision support } \\
\text { (applied geography and regional planning) }\end{array}$ & $\begin{array}{l}\text { Less critical, but often specifically designed to } \\
\text { facilitate a decision-making process, specifically } \\
\text { around the management of common-pool resources } \\
\text { or natural conditions (natural resource } \\
\text { management) }\end{array}$ \\
\hline Power relationship & $\begin{array}{l}\text { Agency, heterogeneity of social groups, power } \\
\text { distribution, logic of actors }\end{array}$ & More functionalist view of society \\
\hline
\end{tabular}

livelihoods in one region, but may drive eutrophication of downstream fisheries or be considered a source of greenhouse gas emissions with severe consequences for communities most vulnerable to climate change elsewhere. At the interface between SES and territoire, territorial ecology emerges as a new field, extending industrial ecology to a larger set of entities. Territorial ecology proposes to analyze social-ecological interactions within a territoire. It analyzes and accounts for social-ecological flows with multiple lenses: biogeochemical processes, land use and land cover, and socioeconomic interactions (Buclet 2015).

Information flows are central to feedback loops. Primary information is obtained from ecosystems, collected through measurements designed by scientists, experts, and public authorities. It then enters the social process of understanding and the public debate, underpinning decision-making by economic agents, public organizations, or associations. These decisions in turn feed back to the ecosystem, affecting harvest or pollution rates, for instance. This loop permits engaging with system complexity while providing an operational setting for observing system outcomes and movement toward preferred SES goals (Plummer 2009), possibly with stakeholders as agents of monitoring (Stringer et al. 2006). SES studies consider other types of information flows acting solely within the social subsystem that may indirectly affect ecosystems. These flows include the process of social learning and the strategic revelation of private information (Laffont and Martimort 2002). SES approaches to information can be articulated within a knowledge network and a shared territorial vision (Junqua and Moine 2007, Ormaux 2007).
Analysis of system evolution and its underlying mechanisms is central in SES tradition and influences its thinking regarding agent adaptation. Modeling the resulting dynamics and interactions across system elements heralds from a tradition of evolutionary analysis in biology and population studies in which agent behavior responds to stimuli from current events according to rules influenced by past experience. Originating from formalized dynamic analysis underpinning some of the SES literature, evolutionary approaches have been adapted to institutional analysis. For instance, institutional change is understood as an evolutionary phenomenon related to social institutions and norms, including evolving social learning capacity (North 2005). There is scope for further fertilization of ideas and methods from this tradition into a more dynamic territorial analysis.

\section{Sense of place and power}

Territoire has a strong foundation in social components, i.e., behavior of social groups and organizations or of individuals, households, or families. These agents are conscious of their environment and their place within that environment. The effectiveness of their control on the territoire they feel they are part of depends on the coordination of multiple agent actions and reflects the capacity to formulate an intention and implement a collective action. This issue of collective action is also well developed within the SES conceptual framework (Ostrom 2005). However, hereafter, we discuss two concepts that are more developed in the territoire tradition and are central to understanding processes of collective action. The first one is 
"sense of place," which contributes to defining identity and reflects the agent's consciousness of environment and of his or her place within it. The second one is power, which contributes to defining governance and agents' abilities to coordinate to control the system.

Sense of place refers to the meanings of and attachment to a setting held by an individual or group (Tuan 1977) and can include an individual and group identity related to a place. Sense of place is related to a set of concepts that have long been part of studies in cultural geography under different forms, particularly through phenomenology (e.g., Tuan 1977), but also in social psychology and related fields (Lewicka 2011). As such, it has been included in social geography and hence in the territoire conceptual framework, where it has been used to develop a critical approach to conservation or development projects. Human geographers now consider sense of place as a keystone in their conceptual framework (Massey 1993, Agnew 1994). Much of the early SES work operated in the vicinity of sense of place research. Initially focusing on indigenous societies' historical intimacy with land, this trend of SES analysis showed that these groups build their cultural identity as well as adaptive institutions and knowledge through experiences in their ecosystems (e.g., Berkes and Folke 1998, Berkes et al. 2003, Tengö and Belfrage 2004). This perspective has been used to question the greater disconnection between human and natural systems, for example, because of urbanization and changes in agriculture (Leopold 1966, Jackson 1994, Folke et al. 2011).

More recently, interest in sense of place has been renewed in SES literature for its potential to motivate and foster stewardship of ecosystems and places (e.g., Andersson et al. 2007, Barthel et al. 2010, Tidball and Stedman 2013, Chapin and Knapp 2015). In this systems view, sense of place is both an outcome of an actor's experience with a place and an attitude that influences behavior of actors and mediates feedbacks between people and their environment (Cumming et al. 2015). Additionally, the influence of sense of place has been used to investigate how actors adapt to changes such as industry closure or climate change (FresqueBaxter and Armitage 2012, Marshall et al. 2012). For example, a strong attachment to a place can have a positive influence on social-ecological resilience in the face of small incremental changes through adaptive capacity, but may hinder transformational change (Marshall et al. 2012). Sense of place has also been shown to serve as a powerful driver for individual and collective action to repair or enhance the traits of a place, e.g., after a disaster has occurred, resulting in virtuous cycles of ecosystem stewardship (Tidball and Stedman 2013, Stedman and Ingalls 2014). The use of sense of place as a construct in SES is still in its infancy, and the SES conceptual framework could be further enhanced by integrating some features of the relatively more nuanced understanding of place, as recently developed and mobilized in social and cultural geography studies, to characterize better the relation between users and systems of resources (Mathevet et al. 2016).

The notion of power is also intrinsic to the territoire conceptual framework. Indeed, derived from ethology, the idea that a territoire results in the actual and symbolic domination of a portion of space implies the exercise of power. Power explains the ability of a group to appropriate and control a specific portion of space. It is then necessary to study power relationships and potential conflicts among all of the agents acting within a territoire. By combining historical and geographical context in the analysis of a given territoire evolution, this tradition integrates the Foucauldian perspective of genealogy, power, and governmentality and may adopt a political ecology lens (Robbins 2012). SES research has been criticized for insufficient treatment of agency and power imbalances as it has been used with a resilience perspective (Cote and Nightingale 2012). However, the SES as defined by Ostrom et al. (1994) specifically addresses power relationships in terms of resource units (either single or multiple) and the claims by multiple groups on a single resource unit or the effects of one stakeholder group on another as mediated either directly or indirectly through resource units. There have also been some innovative responses to this criticism in terms of addressing and theorizing agency in transformative changes (Westley et al. 2013), and a number of SES researchers have explicitly addressed power imbalances and the capacity of individuals and groups to influence social-ecological changes (Peterson 2000, Crona and Bodin 2010).

\section{DEBATES: POTENTIAL FOR ENHANCED UNDERSTANDING OF THE NATURE-SOCIETY RELATION?}

Both the SES and territoire concepts are powerful in their capacity to explain nature-society relations. Both share several features: the differences highlighted here and in the literature have more to do with academic historical traditions rather than fundamental conceptual differences. We next explore how the two traditions function with regard to three core issues of the nature-society interface: resilience, norms, and evolution.

\section{Relevance of these traditions to address specific or general resilience}

Precise definition of nature-society systems is needed to provide suitable context for resilience assessments. Here, we consider how each concept performs when used for resilience assessment. General resilience is related to the essence of the system: What is essential in a system to consider it is still the same system despite its transformations? The structural emphasis of the territoire tradition tends toward a more conservative view considering system components, particularly the social components: people are part of the system, and their social relations are assumed to be the essence of the territoire concept. This view hinders a lot of potential evolution if resilience is an aim. With its more functional emphasis, the SES approach requires the identification of essential system functions, e.g., food security, and assumes that actors and social structures will adapt and change to preserve functions. These adaptations and changes may be violent for some groups of people. The capacity of the SES tradition to assess these possible negative consequences is then at stake. Conceptual tools related to identifying and clarifying power relations or sense of place may help, as well as historical perspectives on sequences of prior transformations. The specific set of values behind the choice of essential functions should be addressed explicitly, as well as the question of who is defining these values.

The specific resilience of a system to a given source of perturbation (Anderies et al. 2006) does not match the territoire approach, which necessarily includes the whole system level with all its connections. The territoire tradition is associated with 
endorsing viewpoints of people within the system at stake. These people cope with all perturbations and cannot elaborate on a specific source of perturbation abstractly or in isolation. Changes in flows and possible feedbacks induced by the system's evolution can be explored through their effects on system functions. Resilience of a state, e.g., clear water state of a lake as in Carpenter et al. (2001), can be assessed through the SES approach, with the possibility for the system to flip into another system, e.g., eutrophic state. A territoire approach will start with the current state of the system and assess the threats for it to remain in its current state under expected perturbations. In this case, "resilience of what" is essentially the resilience of a current situation analyzed through the filter of the multiple perspectives and interests within the population.

Joining the two traditions is promising because it enables: (1) clarity in identifying important system components to enable system dynamics and change, and (2) identification of system components that could be weakened through this change. Building on the differences between the traditions in light of their regard for, and handling of, societal issues, including power relationships and decision-making, can also enrich the analysis and definition of essential functions to be maintained. These, in turn, promote greater awareness of the social implications of a decision being considered, negotiated, or taken.

As a consequence, the concepts emphasize the notion of transitions and their integration across time and space. This emphasis brings the notion of change of the domain of existence itself into the planning process. Beyond panarchy's view of transitions between regimes (Gunderson and Holling 2002), these transitions can be considered as shifting from one dominant domain of resilience to another one, or changing the proxy used to account for general resilience. The transitions between dominant proxies are eventually the place of power issues, with all the underlying norms, as far as these shifts can be influenced.

\section{Normative issues}

In SES, the sets of values that sustain any particular functions, including the social structures and conventions that conservation actions rely on for norms, are more or less explicit. The SES tradition starts with a more positivist stance, seeking to specify predefined categories to describe and explain the dynamics of the system under scrutiny. In this case, creating an objective description is possible because the SES scholar normally sits outside of the system in question. The aim is then to explain the SES trajectory and to provide indicators of its performance and resilience. It is always possible, however, that outcomes of these analyses are used by stakeholders or policy makers out of the scope or domain of the assessment process, thus misconstruing the intended outcomes. This has been criticized as a risk of "instrumentalization" (Voß and Bornemann 2011). SES scholars have become aware of this and seek ways to be more reflexive on this potential bias (Tàbara and Chabay 2013). When involved in the decision process, with an action-research stance, SES analysts bring in implicit norms. Power relations appear more in explaining the dynamics of the system, and emerged as one dimension in a grammar suitable to describe evolution of the SES (Bousquet et al. 2015). SES analysts are hence internalized in the system, and their intervention is analyzed as such with power lenses. A normative input of the SES approach is to recognize that the multiplicity of relationships and feedback loops makes the SES particularly complex, adaptive, and unpredictable.

Territoire is used in a more critical stance, in the same line as political ecology (Batterbury et al. 1997). This includes the analysis of decision processes according to their consequences in terms of power balance, and the evaluation of public policies, with explicit positions of groups of stakeholders (Chaponnière et al. 2012). This emerging trend in evaluation, accepting pluralism, is still in its infancy, developing within the territoire tradition. The space where human activities take place is transformed by culture, reflecting a feeling of belonging to a place or a network. Sense of place is the main defining feature of the territoire. The geographical space becomes a milieu or a nature as soon as people become aware of their environment, build representations, and act upon them. Artificialized, endowed of meaning, possessed, and assimilated, this nature becomes a territoire (Le Berre 1995), enabling and legitimizing the emergence of regulation of its use (Caron 2015). This perspective on naturesociety interactions is more loaded with subjectivity, in opposition to a more functionalist perspective on nature-society interactions that assumes a factual existence of nature, independent of society. This characterizes the tension between those who argue that the environment should be seen principally as a social construct and those who believe that our environment is a factual reality independent of our constructions or representations (Goldman et al. 2011, Robbins 2012). The same debate is played out at the global scale in relation to sustainable development and the definition of "safe and just" operating spaces for humanity (Leach et al. 2013).

\section{Historical viewpoint}

Relation to the past and the use of historical knowledge to explain nature-society relations in their time dependency is a further dimension of debate between both traditions. For social geographers, it is useful to anchor further analysis of socialecological relationships in historical and social dimensions to understand better how power and social structures drive the trajectory of the territoire (Reclus 1876-1894, Robbins 2012). They take a constructivist stance based on the assumption that the very definition of the components of the system the researcher is studying is a social construct that results from the evolution of social representations and uses of physical space. On this basis, some authors criticize the use of reference states for system analysis, and particularly for its ecological components (Crumley 1994, Bestelmeyer 2015). They argue that it is an arbitrary choice and crystalizes a normative stance of the researcher, resulting from a social representation of nature and influenced by power relations and ethical position (Mathevet et al. 2015).

By contrast, reference states are typically used by SES analysts to answer the "Resilience of what?" question. From their understanding, SES analysts develop a more future-oriented stance, elaborating knowledge on drivers of change and generating capacity to handle them to anticipate potential system thresholds. Rather than referring to some idealized notion of the past, they remain open to multiple future objectives of system state. This is sometimes formalized as "viability constraints," entailing exploration of whether they are reachable given initial states, known dynamics, and a set of possible interventions (Aubin 1991, Deffuant and Gilbert 2011). Historical knowledge is still 
used to build this knowledge on drivers of change through the analysis of past trajectories and their explanation based on sets of key variables with independent rates of change. These variables are characterized as fast or slow, the latter of which are growing concerns for environmental policies that may lock in unfair situations because of institutional rigidities explained by slow variables (Brock and Carpenter 2007).

\section{CONCLUSION}

SES and territoire have now come to a convergence, dealing essentially with the same objects and providing suitable ways to specify and discuss what is at stake with an evolution meaningful for some groups of people. This convergence has been enabled via opportunities such as the whole process around the Resilience 2014 conference and the conference itself (http://www. resilience2014.org/), as well as bridging scholars who started to import and tailor concepts from one tradition to the other or developed methods of analysis embedded in communities. However, the differences in their epistemologies and their weighting of social and natural components in driving naturesociety evolution can lead to different perspectives. These differences are problematic when the use of the concepts is primarily for policy-oriented objectives of sustainable management of the nature-society interface. This is problematic because it can lead to inappropriate or unfair policies if some key variables are missed and not brought to light in reflective processes (e.g., adaptive management, monitoring, evaluation, etc.). We have pointed out several possible bridges to strengthen the association of both traditions to improve resilience assessment and management.

SES and territoire have various ways of dealing with system dynamics, space, and society. For example, SES scholars are now working on the specificity of spatial analysis (Cumming et al. 2015). Territoire increasingly engages the analysis of flows and possible feedbacks, importing from ecology the metaphor of metabolism. Emerging fields of "circular economy" and "territorial ecology" (Allais et al. 2015) are consistent with this perspective (although still with a specific view on production rather than resilience), and the inclusion of actor network theory in social geography (Koch 2005) goes in this direction as well. Therefore, territoire is increasingly seen as a matrix for multiple autonomous entities of diverse nature in interaction, including humans, each of them involved in the dynamics of the whole, and hence very close to the perception and evolution of SES.

The common aim of managing resilience of territoire or SESs requires reflexivity. Social geographers have developed an experience of this that could fit current needs of several SES scholars, enhancing their capacity to handle controlled interventions in policy processes related to system function and resilience. Explanation of the framing induced by dominant worldviews through narratives could reinforce social network analysis for power relation identification in the recent evolution of the SES toolbox. Including the nature-society analyst within these networks or sets of worldviews is a key step towards reflexivity, on which both traditions are working.

The temporal dimension, central to the issue of change, can be holistically and fully addressed through the union of both traditions, with analysis more rooted in social history to understand the slow variables involved, and methods turned toward scenario analysis and future more detached from existing components (Peterson et al. 2003). Hence, the union of SES and territoire traditions facilitates a deeper collective thinking of the broader community toward its own development, and we expect this paper will be part of that job.

Responses to this article can be read online at: http://www.ecologyandsociety.org/issues/responses. $\mathrm{php} / 8834$

\section{Acknowledgments:}

The authors thank Biodiversity International, IRSTEA, and UMR 5281 ART-Dév for financial support in organizing the workshop that led to this paper in preparation of the Resilience2014 conference.

\section{LITERATURE CITED}

Adger, W. N. 2000. Social and ecological resilience: are they related? Progress in Human Geography 24(3):347-364. http://dx. doi.org/10.1191/030913200701540465

Agnew, J. 1994. The territorial trap: the geographical assumptions of international relations theory. Review of International Political Economy 1(1):53-80. http://dx.doi.org/10.1080/09692299408434268

Agnew, J. A. 2011. Space and place. Pages 316-330 in J. A. Agnew and D. N. Livingstone, editors. The Sage handbook of geographical knowledge. Sage, Los Angeles, California, USA.

Allais, R., T. Reyes, and L. Roucoules. 2015. Inclusion of territorial resources in the product development process. Journal of Cleaner Production 94(1):187-197. http://dx.doi.org/10.1016/j. jclepro.2015.01.091

Anderies, J. M. 2015. Understanding the dynamics of sustainable social-ecological systems: human behavior, institutions, and regulatory feedback networks. Bulletin of Mathematical Biology 77(2):259-280. http://dx.doi.org/10.1007/s11538-014-0030-z

Anderies, J. M., M. A. Janssen, and E. Ostrom. 2004. A framework to analyze the robustness of social-ecological systems from an institutional perspective. Ecology and Society 9(1):18. [online] URL: http://www.ecologyandsociety.org/vo19/iss1/art18/

Anderies, J. M., B. H. Walker, and A. P. Kinzig. 2006. Fifteen weddings and a funeral: case studies and resilience-based management. Ecology and Society 11(1):21. [online] URL: http:// www.ecologyandsociety.org/vol11/iss1/art21/

Andersson, E., S. Barthel, and K. Ahrné. 2007. Measuring socialecological dynamics behind the generation of ecosystem services. Ecological Applications 17(5):1267-1278. $\underline{\mathrm{http}: / / \mathrm{dx} . \text { doi. }}$ org/10.1890/06-1116.1

Aubin, J.-P. 1991. Viability theory. Birkhäser, Boston, Massachusetts, USA.

Axelrod, R., and W. D. Hamilton. 1981. The evolution of cooperation. Science 211(4489):1390-1396. http://dx.doi.org/10.1126/ science. 7466396 
Badie, B. 1995. La fin des territoires: essai sur le désordre international et sur l'utilité sociale du respect. Fayard, Paris, France.

Barles, S. 2009. Urban metabolism of Paris and its region. Journal of Industrial Ecology 13(6):898-913. http://dx.doi.org/10.1111/ j.1530-9290.2009.00169.x

Barthel, S., C. Folke, and J. Colding. 2010. Social-ecological memory in urban gardens - retaining the capacity for management of ecosystem services. Global Environmental Change 20(2):255-265. http://dx.doi.org/10.1016/j.gloenvcha.2010.01.001

Batterbury, S., T. Forsyth, and K. Thompson. 1997. Environmental transformations in developing countries: hybrid research and democratic policy. Geographical Journal 163 (2):126-132. [online] URL: http://www.jstor.org/stable/3060175

Béné, C., L. Evans, D. Mills, S. Ovie, A. Raji, A. Tafida, A. Kodio, F. Sinaba, P. Morand, J. Lemoalle, and N. Andrew. 2011. Testing resilience thinking in a poverty context: experience from the Niger River basin. Global Environmental Change 21(4):1173-1184. http://dx.doi.org/10.1016/j.gloenvcha.2011.07.002

Berkes, F., J. Colding, and C. Folke. 2003. Navigating socialecological systems: building resilience for complexity and change. Cambridge University Press, Cambridge, UK. http://dx.doi. org/10.1017/cbo9780511541957

Berkes, F., and C. Folke. 1998. Linking social and ecological systems: management practices and social mechanisms for building resilience. Cambridge University Press, Cambridge, UK.

Berque, A. 2000. Médiance, de milieux en paysages. Belin, Paris, France.

Bestelmeyer, B. T. 2015. National assessment and critiques of state-and-transition models: the baby with the bathwater. Rangelands 37(3):125-129. http://dx.doi.org/10.1016/j.rala.2015.03.004

Bonnefoy, J.-L., C. Le Page, J. Rouchier, and F. Bousquet. 2000. Modelling spatial practices and social representations of space using multi-agent systems. Pages 155-168 in G. Ballot and G. Weisbuch, editors. Applications of simulation to social sciences. Hermes, Oxford, UK.

Bousquet, F., P. Robbins, C. Peloquin, and O. Bonato. 2015. The PISA grammar decodes diverse human-environment approaches. Global Environmental Change 34:159-171. http://dx.doi. org/10.1016/j.gloenvcha.2015.06.013

Brock, W. A., and S. R. Carpenter. 2007. Panaceas and diversification of environmental policy. Proceedings of the National Academy of Sciences 104(39):15206-15211. http://dx. doi.org/10.1073/pnas.0702096104

Buclet, N. 2015. Essai d'écologie territoriale: l'exemple d'Aussois en Savoie. CNRS-Alpha, Paris, France.

Caron, P. 2015. Territory: with government and market, a major institutional component to achieve resilience. Natures Sciences Sociétés 23(2):175-182. http://dx.doi.org/10.1051/nss/2015038

Carpenter, S., B. Walker, J. M. Anderies, and N. Abel. 2001. From metaphor to measurement: resilience of what to what? Ecosystems 4(8):765-781. http://dx.doi.org/10.1007/s10021-001-0045-9
Castree, N. 2014. Making sense of nature. Routledge, London, UK.

Chapin, F. S. III, and C. N. Knapp. 2015. Sense of place: a process for identifying and negotiating potentially contested visions of sustainability. Environmental Science and Policy 53(A):38-46. http://dx.doi.org/10.1016/j.envsci.2015.04.012

Chaponnière, A., S. Marlet, S. R. Perret, G. Bouleau, and A. Zaïri. 2012. Methodological pathways to improvements of evaluation approaches: the case of irrigated agriculture performance evaluation. Journal of Multidisciplinary Evaluation 8(18):47-57. [online] URL: http://journals.sfu.ca/jmde/index.php/jmde 1/ article/view/339

Checkland, P. 1981. Systems thinking, systems practice. Wiley, Chichester, UK.

Chertow, M., E. Fugate, and W. Ashton. 2013. The intimacy of human-nature interactions in islands. Pages 315-337 in S. J. Singh, H. Haberl, M. Chertow, M. Mirtl, and M. Schmid, editors. Long term socio-ecological research: studies in society-nature interactions across spatial and temporal scales. Springer, Dordrecht, The Netherlands. http://dx.doi.org/10.1007/978-94-007-1177-8 14

Clark, J. K., and T. V. Stein. 2003. Incorporating the natural landscape within an assessment of community attachment. Forest Science 49(6):867-876.

Coanus, T., J. Comby, D. François, and M. Emmanuel. 2010. Risques et territoires: interroger et comprendre la dimension locale de quelques risques contemporains. Lavoisier, Paris, France.

Cortes, G., and D. Pesche. 2013. Territoire multisitué. L'espace Géographique 42(4):289-292.

Cote, M., and A. J. Nightingale. 2012. Resilience thinking meets social theory: situating social change in social-ecological systems (SES) research. Progress in Human Geography 36(4):475-489. http://dx.doi.org/10.1177/0309132511425708

Cresswell, T. 1996. In placelout of place: geography, ideology, and transgression. University of Minnesota Press, Minneapolis, Minnesota, USA.

Crona, B. I., and Ö. Bodin. 2010. Power asymmetries in smallscale fisheries: a barrier to governance transformability? Ecology and Society 15(4):32. [online] URL: http://www.ecologyandsociety. org/vol15/iss4/art32/

Crumley, C. L. 1994. Historical ecology: cultural knowledge and changing landscapes. School of American Research Press, Santa Fe, New Mexico, USA.

Cumming, G. S., C. R. Allen, N. C. Ban, D. Biggs, H. C. Biggs, D. H. M. Cumming, A. De Vos, G. Epstein, M. Etienne, K Maciejewski, R. Mathevet, C. Moore, M. Nenadovic, and M. Schoon. 2015. Understanding protected area resilience: a multiscale, social-ecological approach. Ecological Applications 25 (2):299-319. http://dx.doi.org/10.1890/13-2113.1

Cumming, G. S., D. H. M. Cumming, and C. L. Redman. 2006. Scale mismatches in social-ecological systems: causes, consequences, and solutions. Ecology and Society 11(1):14. [online] URL: http://www.ecologyandsociety.org/vol11/iss1/ art14l 
de Certeau, M. 1990. L'invention du quotidien: 1. Arts de faire. Gallimard, Paris, France.

Debarbieux, B. 2003. Territoire. 910-912 Pages 21-27 in J. Levy and M. Lussault, editors. Dictionnaire de la géographie et de l'espace des sociétés. Belin, Paris, France.

Debarbieux, B. 2004. The symbolic order of objects and the frame of geographical action: an analysis of the modes and effects of categorisation of the geographical world as applied to the mountains in the West. GeoJournal 60(4):397-405. http://dx.doi. org/10.1023/b:gejo.0000042976.00775.24

Debarbieux, B. 2007. Territoire-territorialité-territorialisation: aujourd'hui encore, et bien moins que demain. Pages - in $\mathbf{M}$. Vanier, editor. Territoires, territorialité, territorialisation: controverses et perspectives. Presses Universitaires de Rennes, Rennes, France.

Deffontaines, J. P., J. Brossier, M. Barbier, M. Benoît, E. Chia, J. L. Fiorelli, M. Gafsi, F. Gras, H. Lemery, and M. Roux. 2000. Water quality, agricultural practices and changes in farming and agrarian systems. Pages 382-390 in M. Collinson, editor. A history of farming systems research. CABI, Wallingford, UK.

Deffuant, G., and N. Gilbert, editors. 2011. Viability and resilience of complex systems: concepts, methods and case studies from ecology and society. Springer, Berlin, Germany. http://dx.doi. org/10.1007/978-3-642-20423-4

Di Méo, G. 1987. Objectivation et représentations des formations sociospatiales: de l'acteur au territoire. Annales de Géographie 96 (537):564-593. [online] URL: http://www.jstor.org/stable/23452233

Di Meo, G. 1998. De l'espace aux territoires: éléments pour une archéologie des concepts fondamentaux de la géographie. L'information Géographique 62(3):99-110. [online] URL: http:// www.persee.fr/doc/ingeo 0020-0093 1998 num 6232586

Di Méo, G. 1999. Géographies tranquilles du quotidien. Une analyse de la contribution des sciences sociales et de la géographie à l'étude des pratiques spatiales. Cahiers de Géographie du Québec 43(118):75-93. http://dx.doi.org/10.7202/022788ar

Di Méo, G., and P. Buléon. 2005. L'espace social: lecture géographique des sociétés. Armand Colin, Paris, France.

Duchêne, F., C. Morel-Journel, T. Coanus, and E. Martinais. 2004. De la culture du risque: paroles riveraines à propos de deux cours d'eau périurbains. L'Aube, Paris, France.

Elden, S. 2010. Land, terrain, territory. Progress in Human Geography 34(6):799-817. http://dx.doi.org/10.1177/0309132510362603

Fabricius, C., and G. Cundill. 2010. Building adaptive capacity in systems beyond the threshold: the story of Macubeni, South Africa. Pages 43-68 in D. Armitage and R. Plummer, editors. Adaptive capacity and environmental governance. Spinger, Berlin, German. http://dx.doi.org/10.1007/978-3-642-12194-4 3

Fall, J. J. 2007. Lost geographers: power games and the circulation of ideas within Francophone political geographies. Progress in Human Geography 31(2):195-216. http://dx.doi.org/10.1177/030$\underline{9132507075369}$

Faysse, N., J.-D. Rinaudo, S. Bento, A. Richard-Ferroudji, M. Errahj, M. Varanda, A. Imache, M. Dionnet, D. Rollin, P. Garin,
M. Kuper, L. Maton, and M. Montginoul. 2014. Participatory analysis for adaptation to climate change in Mediterranean agricultural systems: possible choices in process design. Regional Environmental Change 14(Suppl 1):57-70. http://dx.doi. org/10.1007/s10113-012-0362-X

Fazey, J., J. A. Fazey, J. Fischer, K. Sherren, J. Warren, R. F. Noss, and S. R. Dovers. 2007. Adaptive capacity and learning to learn as leverage for social-ecological resilience. Frontiers in Ecology and the Environment 5(7):375-380. http://dx.doi.org/10.1890/1540-9295 (2007)5[375:ACALTL]2.0.CO;2

Ferrier, J.-P. 1984. Antée 1. La géographie, ça sert d'abord à parler du territoire ou le métier des géographes. Edisud, Aix en Provence, France.

Ferrier, J.-P. 2003. Territoire. Pages 912-917 in J. Lévy and M. Lusault, editors. Dictionnaire de la géographie et de l'espace des sociétés. Belin, Paris, France.

Folke, C. 2006. Resilience: the emergence of a perspective for social-ecological systems analyses. Global Environmental Change 16(3):253-267. http://dx.doi.org/10.1016/j.gloenvcha.2006.04.002

Folke, C., Å. Jansson, J. Rockström, P. Olsson, S. R. Carpenter, F. S. Chapin III, A. S. Crépin, G. Daily, K. Danell, J. Ebbesson, T. Emqvist, V. Galaz, F. Moberg, M. Nilsson, H. Österblom, E. Ostrom, Å Persson, G. Peterson, S. Polasky, W. Steffen, B. Walker, and F. Westley. 2011. Reconnecting to the Biosphere. Ambio 40:719-738. http://dx.doi.org/10.1007/s13280-011-0184-y

Foster, J. B., and B. Clark. 2008. The sociology of ecology: ecological organicism versus ecosystem ecology in the social construction of ecological science, 1926-1935. Organization and Environment 21(3):311-352. http://dx.doi.org/10.1177/1086026608321632

Fresque-Baxter, J. A., and D. Armitage. 2012. Place identity and climate change adaptation: a synthesis and framework for understanding. Wiley Interdisciplinary Reviews: Climate Change 3(3):251-266. http://dx.doi.org/10.1002/wcc.164

Gallopín, G. C. 2006. Linkages between vulnerability, resilience, and adaptive capacity. Global Environmental Change 16 (3):293-303. http://dx.doi.org/10.1016/j.gloenvcha.2006.02.004

Gallopín, G. C., P. Gutman, and H. Maletta. 1989. Global impoverishment, sustainable development and the environment: a conceptual approach. International Social Science Journal 121:375-397.

Goldman, M. J., P. Nadasdy, and M. D. Turner, editors. 2011. Knowing nature: conversations at the intersection of political ecology and science studies. University of Chicago Press, Chicago, Illinois, USA. http://dx.doi.org/10.7208/chicago/9780226301440.001.0001

Gray, S., A. Chan, D. Clark, and R. Jordan. 2012. Modeling the integration of stakeholder knowledge in social-ecological decision-making: benefits and limitations to knowledge diversity. Ecological Modelling 229:88-96. http://dx.doi.org/10.1016/j. ecolmodel.2011.09.011

Gumuchian, H., and B. Pecqueur. 2007. La ressource territoriale. Economica, Paris, France.

Gunderson, L. H., and C. S. Holling, editors. 2002. Panarchy: understanding transformations in human and natural systems. Island Press, Washington, D.C., USA. 
Gunderson, L. H., C. S. Holling, and S. S. Light, editors. 1995. Barriers and bridges to the renewal of ecosystems and institutions. Columbia University Press, New York, New York, USA.

Holling, C. S. 1973. Resilience and stability of ecological systems. Annual Review of Ecology and Systematics 4:1-23. http://dx.doi. org/10.1146/annurev.es.04.110173.000245

Holling, C. S., editor. 1978. Adaptive environmental assessment and management. Wiley, Chichester, UK.

Holling, C. S. 2001. Understanding the complexity of economic, ecological, and social systems. Ecosystems 4(5):390-405. http:// dx.doi.org/10.1007/s10021-001-0101-5

Holling, C. S., and G. K. Meffe. 1996. Command and control and the pathology of natural resource management. Conservation Biology 10(2):328-337. http://dx.doi.org/10.1046/

j.1523-1739.1996.10020328.x

Hornborg, A. 2009. Zero-sum world: challenges in conceptualizing environmental load displacement and ecologically unequal exchange in the world-system. International Journal of Comparative Sociology 50(3-4):237-262. http://dx.doi. org/10.1177/0020715209105141

Hoyaux, A.-F. 2002. Entre construction territoriale et constitution ontologique de l'habitant: introduction épistémologique aux apports de la phénoménologie au concept d'habiter. Cybergeo: European Journal of Geography 216. http://dx.doi. org/10.4000/cybergeo.1824

Jackson, W. 1994. Becoming native to this place. University Press of Kentucky, Lexington, Kentucky, USA. http://dx.doi. org/10.1604/9780813118468

Janssen, M. A., Ö. Bodin, J. M. Anderies, T. Elmqvist, H. Ernstson, R. R. J. McAllister, P. Olsson, and P. Ryan. 2006. Toward a network perspective of the study of resilience in socialecological systems. Ecology and Society 11(1):15. [online] URL: http://www.ecologyandsociety.org/vol11/iss1/art15/

Junqua, G., and H. Moine. 2007. Utilisation de l'écologie industrielle et de l'intelligence économique territoriale pour le développement durable d'une zone industrialo-portuaire. Déchets 46:19-23. http://dx.doi.org/10.4267/dechets-sciences-techniques. 1608

Kinzig, A. P., P. Ryan, M. Etienne, H. Allyson, T. Elmqvist, and B. H. Walker. 2006. Resilience and regime shifts: assessing cascading effects. Ecology and Society 11(1):20. [online] URL: http://www.ecologyandsociety.org/vol11/iss1/art20/

Koch, A. 2005. Autopoietic spatial systems: the significance of actor network theory and system theory for the development of a system theoretical approach of space. Social Geography 1 (1):5-14. http://dx.doi.org/10.5194/sg-1-5-2005

Laffont, J.-J., and D. Martimort. 2002. The theory of incentives: the principal-agent model. Princeton University Press, Princeton, New Jersey, USA.

Le Berre, M. 1995. Territoires. Pages 601-622 in A. Bailly, R. Ferras, and D. Pumain, editors. Encyclopédie de géographie. Second edition. Economica, Paris, France.

Leach, M., K. Raworth, and J. Rockström. 2013. Between social and planetary boundaries: navigating pathways in the safe and just space for humanity. Pages 84-89 in ISSC and UNESCO World Social Science Report 2013: changing global environments. OECD and UNESCO, Paris, France. [online] URL: http://www.unesco. org/new/en/social-and-human-sciences/resources/reports/world-socialscience-report-2013/

Lefebvre, H. 1974. La production de l'espace. Anthropos, Paris, France.

Leopold, A. 1966. A sand county almanac: with essays on conservation from Round River. Ballantine Books, New York, New York, USA.

Lepart, J., and P. Marty. 2006. Des réserves de nature aux territoires de la biodiversité: l'exemple de la France. Annales de Géographie 115(651):485-507. http://dx.doi.org/10.3406/geo.2006.21284

Levin, S. A. 1999. Fragile dominion: complexity and the commons. Perseus, Cambridge, Massachusetts, USA.

Lévy, J. 2003. Territoire. Pages 907-910 in J. Lévy and M. Lussault, editors. Dictionnaire de la géographie et des sociétés. Belin, Paris, France.

Lewicka, M. 2011. Place attachment: How far have we come in the last 40 years? Journal of Environmental Psychology 31 (3):207-230. http://dx.doi.org/10.1016/j.jenvp.2010.10.001

Liu, J., T. Dietz, S. R. Carpenter, C. Folke, M. Alberti, C. L. Redman, S. H. Schneider, E. Ostrom, A. N. Pell, J. Lubchenco, W. W. Taylor, Z. Ouyang, P. Deadman, T. Kratz, and W. Provencher. 2007. Coupled human and natural systems. Ambio 36(8):639-649. http://dx.doi.org/10.1579/0044-7447(2007)36[639: chans $] 2.0 .00 ; 2$

Mace, G. M. 2014. Whose conservation? Science 345 (6204):1558-1560. http://dx.doi.org/10.1126/science.1254704

Marshall, N. A., S. E. Park, W. N. Adger, K. Brown, and S. M. Howden. 2012. Transformational capacity and the influence of place and identity. Environmental Research Letters 7(3):034022. http://dx.doi.org/10.1088/1748-9326/7/3/034022

Martin, E., and H. Stahn. 2013. Potential conflict and inefficiencies arising in agri-environmental management. Journal of Agricultural Economics 64(2):423-445. http://dx.doi. org/10.1111/j.1477-9552.2012.00374.x

Massey, D. 1993. Power-geometry and a progressive sense of place. Pages 59-69 in J. Bird, B. Curtis, T. Putnam, G. Robertson, and L. Tickner, editors. Mapping the futures: local cultures, global change. Routledge, London, UK.

Mathevet, R., F. Bousquet, C. Le Page, and M. Antona. 2003. Agent-based simulations of interactions between duck population, farming decisions and leasing of hunting rights in the Camargue (southern France). Ecological Modelling 165 (2-3):107-126. http://dx.doi.org/10.1016/S0304-3800(03)00098$\underline{\mathrm{X}}$

Mathevet, R., and L. Godet. 2015. Pour une géographie de la conservation. Page 400 in R. Mathevet and L. Godet, editors. Biodiversités, natures and sociétés. L'Harmattan, Paris, France.

Mathevet, R., N. L. Peluso, A. Couespel, and P. Robbins. 2015. Using historical political ecology to understand the present: water, reeds, and biodiversity in the Camargue Biosphere Reserve 
(southern France). Ecology and Society 20(4):17. http://dx.doi. org/10.5751/es-07787-200417

Mathevet, R., J. D. Thompson, C. Folke, and F. S. Chapin III. 2016. Protected areas and their surrounding territory: socioecological systems in the context of ecological solidarity. Ecological Applications 26(1):5-16. http://dx.doi.org/10.1890/14-0421

McGinnis, M. D., and E. Ostrom. 2014. Social-ecological system framework: initial changes and continuing challenges. Ecology and Society 19(2):30. http://dx.doi.org/10.5751/es-06387-190230

Meadows, D. H. 2008. Thinking in systems: a primer. Chelsea Green, White River Junction, Vermont, USA.

Miller, J. H., and S. E. Page. 2009. Complex adaptive systems: an introduction to computational models of social life. Princeton University Press, Princeton, New Jersey, USA. http://dx.doi. org/10.1515/9781400835522

Mitchell, M. 2009. Complexity: a guided tour. Oxford University Press, Oxford, UK.

Moine, A. 2006. Le territoire comme un système complexe: un concept opératoire pour l'aménagement et la géographie. L'espace Géographique 35(2):115-132.

North, D. C. 2005. Understanding the process of economic change. Princeton Univeristy Press, Princeton, New Jersey, USA.

Ormaux, S. 2007. Methods for territorial intelligence. Pages 25-27 in International Conference of Territorial Intelligence, Alba Iulia 2006. Volume 2. Proceedings of caENTI - Coordination Action of the European Network of Territorial Intelligence, Aeternitas, Alba Iulia, 2007. [online] URL: http://www.territorial-intelligence.eu/ index.php/alba06/Ormaux

Ostrom, E. 2005. Understanding institutional diversity. Princeton University Press, Princeton, New Jersey, USA.

Ostrom, E. 2007. A diagnostic approach for going beyond panaceas. Proceedings of the National Academy of Sciences 104 (39):15181-15187. http://dx.doi.org/10.1073/pnas.0702288104

Ostrom, E. 2009. A general framework for analyzing sustainability of social-ecological systems. Science 325:419-422. http://dx.doi.org/10.1126/science.1172133

Ostrom, E., R. Gardner, and J. Walker. 1994. Rules, games, and common-pool resources. University of Michigan Press, Ann Arbor, Michigan, USA.

Peterson, G. 2000. Political ecology and ecological resilience: an integration of human and ecological dynamics. Ecological Economics 35(3):323-336. http://dx.doi.org/10.1016/S0921-8009 (00)00217-2

Peterson, G. D., G. S. Cumming, and S. R. Carpenter. 2003. Scenario planning: a tool for conservation in a uncertain world. Conservation Biology 17(2):358-366. http://dx.doi.org/10.1046/ j.1523-1739.2003.01491.x

Plummer, R. 2009. The adaptive co-management process: an initial synthesis of representative models and influential variables. Ecology and Society 14(2):24. [online] URL: http://www. ecologyandsociety.org/vol14/iss2/art24/
Raffestin, C. 1986. Ecogénèse territoriale et territorialités. Pages 175-185 in F. Auriac and R. Brunet, editors. Espaces, jeux et enjeux. Fayard, Paris, France.

Reclus, E. 1876-1894. Nouvelle géographie universelle: la terre et les hommes. Hachette, Paris, France.

Robbins, P. 2012. Political ecology: a critical introduction. Second edition. Wiley-Blackwell, Chichester, UK.

Rougerie, G., and N. Beroutchavili. 1991. Géosystèmes et paysages. Armand Colin, Paris, France.

Sack, R. D. 1986. Human territoriality: its theory and history. Cambridge University Press, Cambridge, UK.

Sarker, A., H. Ross, and K. K. Shrestha. 2008. A common-pool resource approach for water quality management: an Australian case study. Ecological Economics 68(1-2):461-471. http://dx.doi. org/10.1016/j.ecolecon.2008.05.001

Sassen, S. 2008. Territory, authority, rights: from medieval to global assemblages. Princeton University Press, Princeton, New Jersey, USA. http://dx.doi.org/10.1515/9781400828593

Séchet, R., and V. Veschambre. 2006. Penser et faire la géographie sociale: contribution à une épistémologie de la géographie sociale. Presses Universitaires de Rennes, Rennes, France. http://dx.doi. org/10.4000/books.pur.362

Selman, P. H. 2000. Environmental planning: the conservation and development of biophysical resources. Second edition. Sage, Thousand Oaks, California, USA.

Singh, S. J., H. Haberl, M. Chertow, M. Mirtl, and M. Schmid, editors. 2013. Long term socio-ecological research: studies in society-nature interactions across spatial and temporal scales. Springer, Dordrecht, The Netherlands. http://dx.doi. org/10.1007/978-94-007-1177-8

Stedman, R. C., and M. Ingalls. 2014. Topophilia, biophilia and greening in the red zone. Pages 129-144 in K. G. Tidball and M. E. Krasny, editors. Greening in the red zone: disaster, resilience and community greening. Springer, Dordrecht, The Netherlands.

Stringer, L. C., A. J. Dougill, E. Fraser, K. Hubacek, C. Prell, and M. S. Reed. 2006. Unpacking "participation" in the adaptive management of social-ecological systems: a critical review. Ecology and Society 11(2):39. [online] URL: http://www. ecologyandsociety.org/vol11/iss2/art39/

Tàbara, J. D., and I. Chabay. 2013. Coupling human information and knowledge systems with social-ecological systems change: reframing research, education, and policy for sustainability. Environmental Science and Policy 28:71-81. http://dx.doi. org/10.1016/j.envsci.2012.11.005

Tengö, M., and K. Belfrage. 2004. Local management practices for dealing with change and uncertainty: a cross-scale comparison of cases in Sweden and Tanzania. Ecology and Society 9(3):4. [online] URL: http://www.ecologyandsociety.org/vo19/iss3/art4/

Tidball, K., and R. Stedman. 2013. Positive dependency and virtuous cycles: from resource dependence to resilience in urban social-ecological systems. Ecological Economics 86:292-299. http://dx.doi.org/10.1016/j.ecolecon.2012.10.004 
Tuan, Y.-F. 1977. Space and place: the perspective of experience. University of Minnesota Press, Minneapolis, Minnesota, USA.

Tuan, Y.-F. 1979. Space and place: humanistic perspective. Pages 387-427 in S. Gale and G. Olsson, editors. Philosophy in geography. Springer, Dordrecht, The Netherlands. http://dx.doi. org/10.1007/978-94-009-9394-5 19

Vanier, M. 2008. Le pouvoir des territoires: essai sur l'interterritorialité. Economica-Anthropos, Paris, France.

Vant, A. 1986. A propos de l'impact du spatial sur le social. Pages 97-110 in F. Auriac and R. Brunet, editors. Espaces, jeux et enjeux. Fayard, Paris, France.

von Bertalanffy, L. 1968. General system theory: foundations, development, applications. George Braziller, New York, New York, USA.

Voß, J.-P., and B. Bornemann. 2011. The politics of reflexive governance: challenges for designing adaptive management and transition management. Ecology and Society 16(2):9. [online] URL: http://www.ecologyandsociety.org/vol16/iss2/art9/

Walker, B. H., L. H. Gunderson, A. P. Kinzig, C. Folke, S. R. Carpenter, and L. Schulz. 2006. A handful of heuristics and some propositions for understanding resilience in social-ecological systems. Ecology and Society 11(1):13. [online] URL: http://www. ecologyandsociety.org/vol11/iss1/art13/

Walker, B., C. S. Holling, S. R. Carpenter, and A. Kinzig. 2004. Resilience, adaptability, and transformability in social-ecological systems. Ecology and Society 9(2):5. [online] URL: http://www. ecologyandsociety.org/vo19/iss2/art5/

WCED (World Commission on Environment and Development). 1987. Our common future. Oxford University Press, Oxford, UK.

Weber, M. 1978. Economy and society: an outline of interpretive sociology. G. Roth and C. Wittich, editors. University of California Press., Berkeley, California, USA.

Westley, F. R., O. Tjornbo, L. Schultz, P. Olsson, C. Folke, B. Crona, and Ö. Bodin. 2013. A theory of transformative agency in linked social-ecological systems. Ecology and Society 18(3):27. http://dx.doi.org/10.5751/es-05072-180327

Wilson, B. 1990. Systems: concepts, methodologies and applications. Second edition. Wiley, Chichester, UK. 